\title{
Influences of cyclones on chlorophyll a concentration and Synechococcus abundance in a subtropical western Pacific coastal ecosystem
}

\author{
Jeng Chang ${ }^{1, *}$, Chih-Ching Chung ${ }^{2, * *}$, Gwo-Ching Gong ${ }^{3}$ \\ ${ }^{1}$ Institute of Marine Biology, ${ }^{2}$ Department of Aquaculture and ${ }^{3}$ Department of Oceanography, \\ National Taiwan Ocean University, Keelung 202-24, Taiwan, ROC
}

\begin{abstract}
The effects of tropical cyclones on seasonal variations in phytoplankton biomass were studied at a station on the northern coast of Talwan. Water temperature at the study site varied between 17 and $30^{\circ} \mathrm{C}$ in 1994 . Both chlorophyll a concentration and Synechococcus abundance were low in the winter and started to increase when surface water became warmer than $25^{\circ} \mathrm{C} . \ln \mathrm{July}$ and August, 4 cyclones struck the study site. All cyclones dramatically reduced phytoplankton biomass in the water column, and caused significant increases in nitrate, nitrite, phosphate, and silicate concentrations. Blooms of phytoplankton with total chlorophyll a concentration as high as $4.2 \mu \mathrm{Hg} \mathrm{l}^{-1}$ were observed after cyclonic disturbances, and were mainly composed of species greater than $5 \mu$ m in size. Our results suggest that cyclones disturb coastal marine ecosystems in a consistent way, and induce ordered and predictable changes in a phytoplankton community.
\end{abstract}

KEY WORDS: Chlorophyll a Cyclone Seasonal varlation Synechococcus - Ultraplankton

\section{INTRODUCTION}

Episodic disturbances and transient changes have profound influences on both the abundance and production of marine phytoplankton. Recent studies suggest that a significant portion of the annual primary production in the ocean is generated during periods following intermittent disturbances (Platt \& Harrison 1985). Cyclones with strong wind and heavy rainfall represent extreme cases of these disturbances. In the open ocean, a hurricane may deepen the mixing depth by 20 to $30 \mathrm{~m}$ (Malone et al. 1993). The nutrients injected to the euphotic zone by such events may trigger the growth of phytoplankton and enhance the sinking fluxes of diatoms, dinoflagellates, bacteria, fecal pellets, and other forms of particulate organic matter (Goldman 1988, Taylor 1989). In coastal environments, cyclones destroy phytoplankton communi-

\footnotetext{
-E-mail: b0176@intou66.ntou.edu.tw

-Present address: Institute of Fisheries Science, Natronal Taiwan University, Taipei 106-17, Taiwan, ROC
}

ties by flushing near-shore locations with offshore water. Shortly after a cyclone event, however, increases in phytoplankton biomass and productivity are frequently observed (Furnas 1989, Delesalle et al. 1993)

It is difficult to have a clear understanding of the effects of cyclones on phytoplankton dynamics because the occurrence and path of a cyclone cannot be predicted accurately. Most reports to date described serendipitous encounters with a single cyclone or storm. In addition, the severe weather condition makes sampling during the storm period impossible, especially at more offshore stations. Taiwan is a large island occupying a section of the western Pacific continental shelf between the latitudes of $22^{\circ}$ and $25^{\circ} \mathrm{N}$ (Fig. 1). In summer, Taiwan is on a path frequently traveled by powerful cyclones called typhoons. Between July and October 1994, 5 typhoons went through the northern part of Taiwan. We took this opportunity to accomplish a high frequency sampling schedule for the first 4 typhoons at a coastal station near our laboratory. The data set contained repetitive 


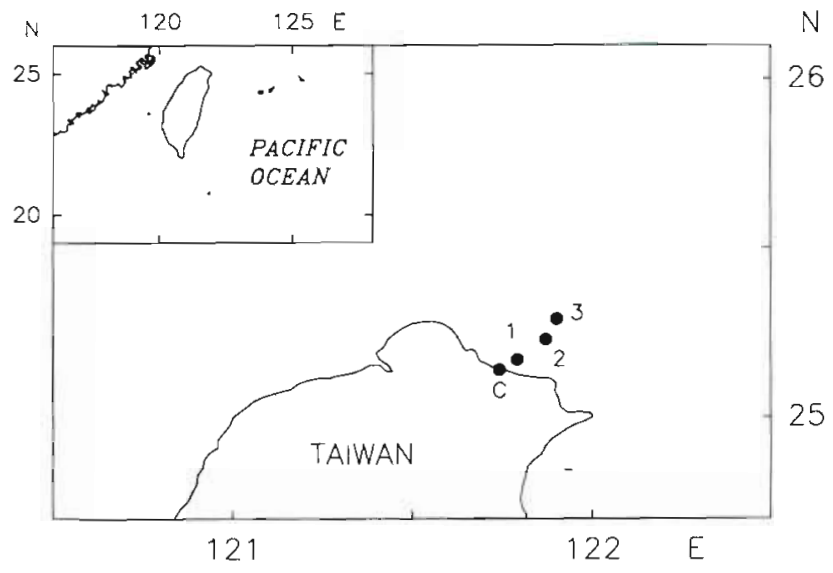

Fig. 1. Locations of the coastal sampling site (Stn C) and 3 offshore stations (Stns 1 to 3). Insert: geographic position of Taiwan

measurements of size fractionated chlorophyll concentration, Synechococcus cell abundance, and nutrient level which allowed us to establish a general trend of the impact of cyclones on coastal marine phytoplankton, and to examine the variability of community responses to individual incidents.

\section{MATERIALS AND METHODS}

A coastal station $\left(25^{\circ} 09.4^{\prime} \mathrm{N}, 121^{\circ} 46.3^{\prime} \mathrm{E}\right)$ was established on a rocky shore near Taiwan Ocean University from January to December 1994 (Fig. 1). Weekly surface samples were taken using a bucket for chlorophyll a (chl a) determination and phytoplankton cell counts. The sampling time was always within $1 \mathrm{~h}$ of high tide, and water temperature was measured immediately after the bucket cast. During the summer, when a typhoon warning was in effect, sampling frequency was increased to once per day, and this sampling schedule was maintained until 3 to $5 \mathrm{~d}$ after the typhoon had passed. During this period, additional samples were obtained for nutrient analysis and salinity determination. The year-round weather parameters, including daily wind speed, rainfall, and solar irradiance, were obtained from the local weather bureau at Keelung City (Taiwan). The irradiance was measured as daily energy input due to electromagnetic waves with wavelengths between 300 and $3000 \mathrm{~nm}$. On August 31, extra samples were taken at 5.5 and $2.5 \mathrm{~h}$ before the high tide, respectively, to assess the variation caused by tidal excursion. In addition, the spatial variation between the coastal station and offshore waters was investigated during a cruise on board RV 'Ocean Researcher II' on the same day. The positions of stations are illustrated in Fig. 1. The temperature and salinity at these offshore stations were measured by a CTD
(SBE9/11, Seabird Inc., Bellevue, WA, USA). Water samples were collected from $5 \mathrm{~m}$ depth with a rosette sampler equipped with 2.51 Go-Flo bottles (General Oceanics, Miami, FL, USA), and were processed the same way as samples collected at the coastal station

Water samples collected at the coastal station were transported to the laboratory within 20 min for further analysis. Chl a concentrations were measured in triplicate (in duplicate for offshore samples) using a Turner Designs Fluorometer (Model 10-AU-005) according to standard procedures (Parsons et al. 1984). The volume filtered was $60 \mathrm{ml}$ for coastal waters and $1000 \mathrm{ml}$ tor offshore waters, respectively. The average coefficient of variation among replicates was $10.4 \%$. Ultraplankton chl a concentration was determined after passing sea water through a $5 \mu \mathrm{m}$ mesh Nytex screen. Synechococcus cells in 1 to $2 \mathrm{ml}$ sea water were collected on a $0.2 \mu \mathrm{m}$ pore size Nuclepore filter, and their abundance was enumerated under a fluorescence microscope (Nikon Optiphot-2) at $1000 \times$. Blue light from 450 to $490 \mathrm{~nm}$ was used for excitation, and emitted fluorescence was detected above $520 \mathrm{~nm}$ (Waterbury et al. 1987). Cells in 20 randomly selected fields (diameter: $141 \mu \mathrm{m}$ ) were summed, and were used to estimate population densities. Both yellow and red fluorescing cells smaller than $5 \mu \mathrm{m}$ were recorded. However, since the latter cell type was often absent in our samples, only phycoerythrin-containing cells were reported as Synechococcus here.

Another $500 \mathrm{ml}$ of sample was preserved with acidic Lugol's solution for identification of major species (Throndsen 1978). The nutrient samples were quickly frozen in liquid $\mathrm{N}_{2}$ and then stored at $-15^{\circ} \mathrm{C}$ until analysis. The concentrations of nitrate and nitrite were determined by the pink azo dye method (Parsons et al. 1984, Pai et al. 1990). Phosphate and silicate were measured by the molybdenum blue and the silicomolybdenum blue method (Pai et al. 1990). Salinity samples collected from the coastal station were analyzed by an Autosal salinometer (model $8400 \mathrm{~B}$, Guildline Inc., Orlando, FL, USA).

\section{RESULTS}

Clear seasonal cycles of water temperature, solar irradiance, and phytoplankton biomass were observed at the coastal station (Fig. 2). Water temperature in February was around $17^{\circ} \mathrm{C}$. From March to July, both water temperature and monthly mean irradiance increased toward their annual maxima. The typical summer water temperature was around $29^{\circ} \mathrm{C}$. During winter and spring, the phytoplankton biomass indicated by chl a concentration seldom exceeded $0.5 \mu \mathrm{g}$ $\mathrm{I}^{-1}$ (Fig. 2). At the end of May, when water temperature 


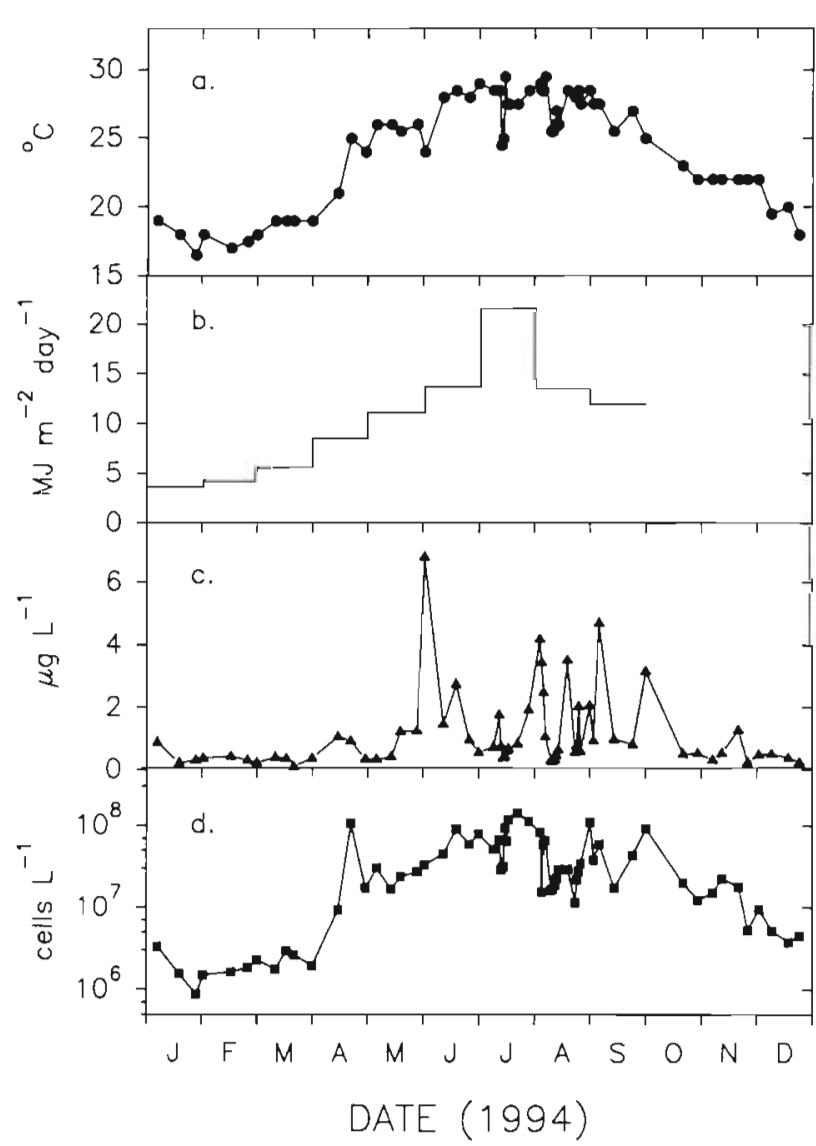

Fig. 2. Annual variations of (a) water temperature; (b) daily integrated solar irradiance; (c) total chl a concentration; and (d) abundance of Synechococcus at the coastal station (Stn C)

had stayed above $25^{\circ} \mathrm{C}$ for a period of time, we observed the first sudden increase of phytoplankton as the chl a concentration increased sharply to about $7 \mu \mathrm{g}$ $\mathrm{l}^{-1}$. However, the chl a concentration did not maintain this high level for the entire summer. Instead, a sharp decrease usually occurred several weeks after the initial outburst. Such blooms repeated themselves many times during the summer, and ceased to appear after September when the water temperature dropped below $25^{\circ} \mathrm{C}$. On the other hand, the seasonal cycle of Synechococcus was somewhat different (Fig. 2). Its population density increased about 50 -fold from $2.0 \times$
$10^{6}$ to $1.1 \times 10^{8}$ cells $\mathrm{l}^{-1}$ in April, and maintained this high level until September. Starting from mid-September, Synechococcus abundance decreased gradually as water became cooler.

Between the high and low tide on August 31, temperature and salinity only varied slightly (Table 1). For chl a and Synechococcus cell counts, high values appeared near the high tide. Variations in concentrations of major nutrients were also observed. A general pattern was that the maximum values for nutrient concentration and phytoplankton biomass were about twice the minimum values (Table 1 ).

The physical and chemical characteristics of sea water at the coastal station were somewhat different from those at offshore stations (Fig. 3). The variation in salinity was small; however, water temperature at the coastal station was $1.5^{\circ} \mathrm{C}$ higher. This was probably a result of direct solar heating on sea surface since water samples were taken from the $0 \mathrm{~m}$ depth at the coastal station. As for nutrient concentrations, while phosphate level decreased toward the offshore direction, the same trend was not observed for nitrate. The nitrate concentration at the coastal station was $2.3 \mu \mathrm{M}$, which was lower than those found at Stns 1 and 3. Chl a concentration at the coastal station was about twice the values measured in offshore waters, but the fraction contributed by ultraplankton was much lower (Fig. 3).

The first cyclone of 1994, typhoon Tim, passed through our study site on July 10, and brought strong wind and heavy rainfall (Fig. 4). The water temperature at the coastal station dropped $4^{\circ} \mathrm{C}$ in $24 \mathrm{~h}$ from 28.5 to $24.5^{\circ} \mathrm{C}$. The typhoon also caused chl a concentration to decrease for 2 consecutive days from 1.8 to $0.4 \mu \mathrm{g} \mathrm{l^{-1 }}$. Similar decreases were observed in ultraplankton and Synechococcus abundance (Fig. 4). When typhoon Tim had moved away, water temperature returned to the pre-cyclone level in $2 \mathrm{~d}$, and population density of Synechococcus recovered at a comparable rate. After reaching a density of $1.2 \times 10^{7}$ cells $1^{-1}$, the abundance of Synechococcus did not change much until the arrival of next cyclone in August. Total and ultraplankton chlorophyll started to recover from the third day after typhoon Tim (Fig. 4). Total chl a increased continuously for $20 \mathrm{~d}$, and reached $4.2 \mathrm{\mu g} \mathrm{l}^{-1}$

Table 1 Variation of chemical and biological characteristics at the coastal station during a tidal cycle on August 31, 1994. Time of high tide: $15.36 \mathrm{~h}$

\begin{tabular}{|c|c|c|c|c|c|c|c|c|c|}
\hline \multirow{2}{*}{$\begin{array}{l}\text { Time of day } \\
\text { (h) }\end{array}$} & \multirow[t]{2}{*}{ Temp. $\left({ }^{\circ} \mathrm{C}\right)$} & \multirow[t]{2}{*}{ Salinity } & \multicolumn{2}{|c|}{ Chl $a\left(\mu \mathrm{gl}^{-1}\right)$} & \multirow{2}{*}{$\begin{array}{l}\text { Synechococcus } \\
\left(\times 10^{8} \text { cells } l^{-1}\right)\end{array}$} & \multicolumn{4}{|c|}{ Nutrient concentration $(\mu \mathrm{M})$} \\
\hline & & & Total & $<5 \mu \mathrm{m}$ & & $\mathrm{NO}_{3}$ & $\mathrm{NO}_{2}$ & $\mathrm{PO}_{4}$ & $\mathrm{SiO}_{3}$ \\
\hline $10: 00$ & 28.0 & 32.7 & 1.2 & 0.5 & 0.4 & 3.7 & 0.6 & 0.4 & 4 \\
\hline $13: 00$ & 28.5 & 33.0 & 1.3 & 0.7 & 1.2 & 4.5 & 0.3 & 0.2 & 9 \\
\hline $15: 00$ & 28.5 & 32.9 & 2.1 & 0.9 & 1.1 & 2.3 & 0.4 & 0.1 & 10 \\
\hline
\end{tabular}




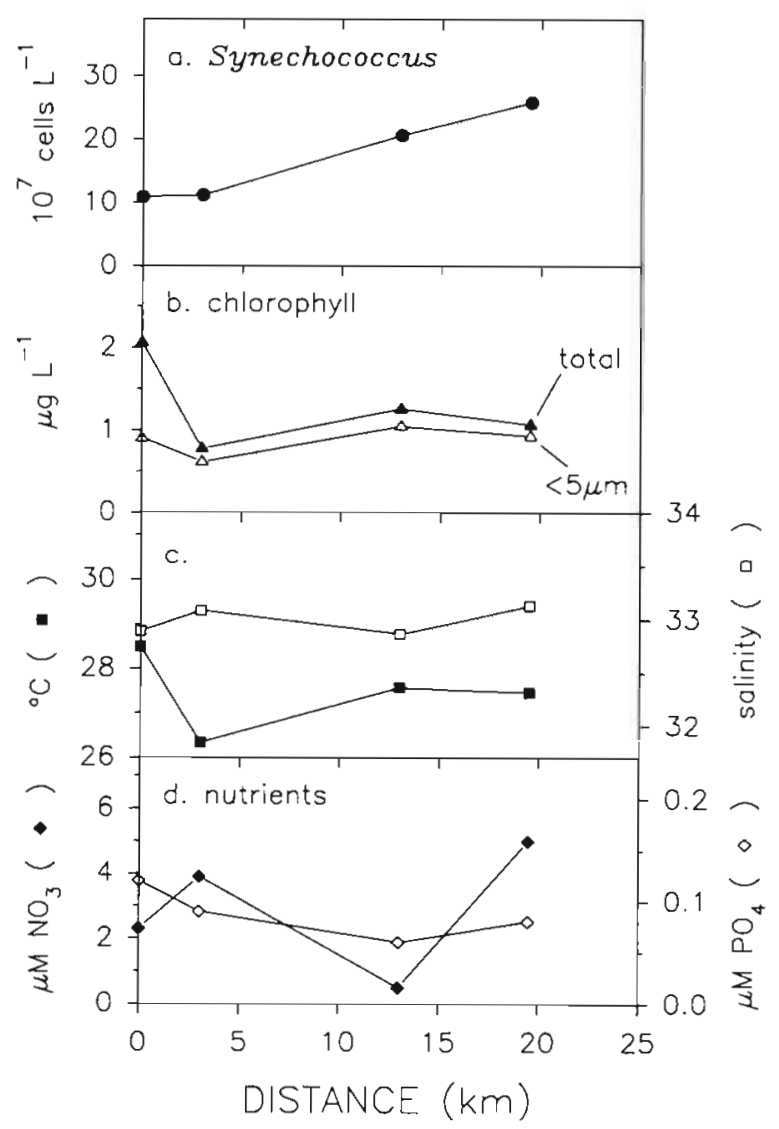

Fig. 3. Comparison of biological and hydrographic characteristics at the coastal station (Stn C) to those in offshore waters (Stns 1 to 3): (a) Synechococcus abundance, (b) total and ultraplankton $(<5 \mu \mathrm{m}) \mathrm{chl}$ a concentration; (c) temperature and salinity; and (d) nitrate and phosphate concentrations. Distance was determined with the coastal station as $0 \mathrm{~km}$. Water samples were taken from $0 \mathrm{~m}$ depth at the coastal station, and from $5 \mathrm{~m}$ at the offshore stations

at the beginning of August. The increase in ultraplankton chlorophyll was not as drastic which indicated that species greater than $5 \mu \mathrm{m}$ were responsible for the rapid increase of phytoplankton following a cyclone. Microscopic examination revealed that the dominant species during the bloom period were chain forming diatoms such as Skeletonema costatum, Chaetoceros spp., and Nitzschia spp.

On August 3 and 8, typhoons Caitlin and Doug affected Taiwan in a tight sequence. The intensity of typhoon Caitlin was weak, and only a minor decrease in water temperature was noticed (Fig. 4). However. Synechococcus showed a strong response and declined to a level lower than that caused by the previous typhoon. After typhoon Caitlin, Synechococcus only took $1 \mathrm{~d}$ to recover, but its abundance decreased again when typhoon Doug arrived several days later. Typhoon Doug was a violent cyclone judged by its

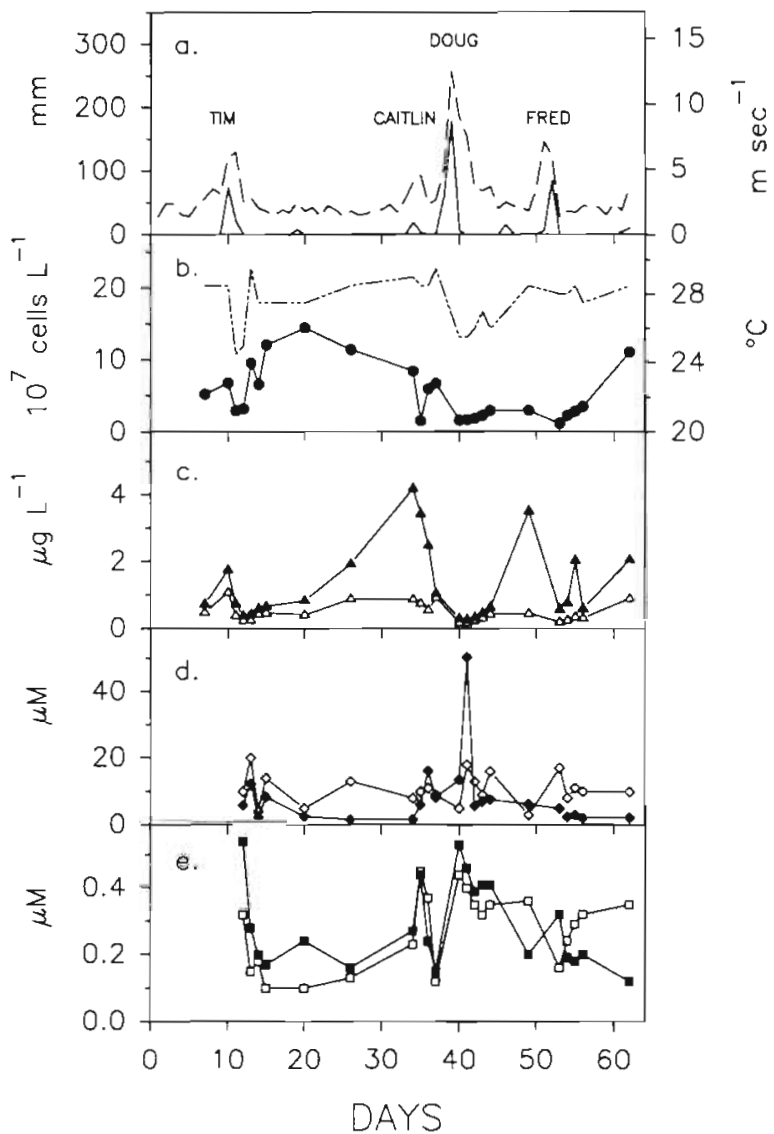

Fig. 4. Sequential changes in the water column at the coastal station induced by cyclones in summer 1994. Time series of (a) rainfall (-) and dally mean wind speed ( - - ) ; (b) water temperature (--) and Synechococcus abundance ( $\bullet$ ); (c) total ( $\mathbf{\Delta}$ ) and ultraplankton ( $\Delta$ ) chl a concentration; (d) nitrate $(\bullet)$ and silicate (0) concentrations; (e) nitrite (ㅁ) and phosphate (ロ) concentrations

wind speed and rainfall (Fig. 4). Before the declining chl a triggered by typhoon Caitlin had a chance to recover, typhoon Doug forced it down to a new low level of $0.3 \mu \mathrm{g} \mathrm{l}^{-1}$. The increase in chl a concentration after typhoon Doug was similar to what followed typhoon Tim, and formed another bloom with $3.5 \mu \mathrm{g}$ chl $a \mathrm{l}^{-1}$ in $10 \mathrm{~d}$. Again, the increase was mainly due to species larger than $5 \mu \mathrm{m}$. For Synechococcus, although the cell number multiplied for $4 \mathrm{~d}$, it never returned to the pre-Caitlin level.

Two weeks later, typhoon Fred struck northern Taiwan on August 21, and induced a similar sequence of changes at the coastal station (Fig. 4). The only difference was that a lag phase was absent during the recovery course of phytoplankton larger than $5 \mu \mathrm{m}$. Total chl a jumped from 0.6 to $2.0 \mu \mathrm{g} \mathrm{l}^{-1}$ in $2 \mathrm{~d}$, but suddenly dropped back to $0.6 \mathrm{Hg} \mathrm{l}^{-1}$ on the third day.

All 4 cyclones induced pulsed increases in nutrient concentrations at the coastal station (Fig 4). However, 
not all nutrients peaked at the same time. In general, phosphate and nitrite peaks appeared together, and were observed within $1 \mathrm{~d}$ after a cyclone. On the other hand, the nitrate peak often appeared together with the silicate peak, but their occurrence was 1 additional day behind the corresponding phosphate peak (Fig. 4). A somewhat different pattern was observed after typhoon Fred. The nitrate peak was absent, and the timing of the nitrite pulse was shifted.

\section{DISCUSSION}

Compared to the temperate and the tropical regions, the seasonal cycle of phytoplankton off the coast of northern Taiwan has some unique features. From April to November, phytoplankton at our coastal station formed numerous small blooms with different amplitudes and intervals (Fig. 2). Such a pattern resembled the temporal variation typically found in the tropics. The difference was that, at a tropical location such as the Jamaican coast (Hopcroft \& Roff 1990), this pattern would persist through the entire year. On the other hand, although an obvious seasonal change was recorded at our study site, a spring bloom typically found in temperate coastal waters (e.g. Peterson 1986) was absent.

For Synechococcus, its abundance at our coastal station was closely related to water temperature (Fig. 5a). This was true even when temperature fluctuated rapidly due to passing cyclones in the summer (Fig. 5). The same tight relationship with water temperature was also observed for Synechococcus in Woods Hole Harbor (Cape Cod, USA; Waterbury et al. 1987). However, Synechococcus abundance in temperate regions started to climb when the water temperature was only $5^{\circ} \mathrm{C}$ (Waterbury et al. 1987), but cell concentration at our study site remained at the winter level until water temperature exceeded $19^{\circ} \mathrm{C}$ (Fig. 2). One explanation is that tropical waters are dominated by Synechococcus species sensitive to low temperature. Alternatively, Synechococcus abundance is probably not directly controlled by temperature. Other environmental factors that varied seasonally, such as solar irradiance and mixing strength, may play a more important role. At the coastal station, both total and ultraplankton chl a concentration also increased with water temperature, but the correlation was weaker (Fig. 5b, c).

The most immediate effect of cyclones was a sudden decrease in phytoplankton biomass (Fig. 4). Compared to the normal level prior to a cyclone, chl a concentration was reduced by 75 to $93 \%$, and Synechococcus abundance was reduced by 56 to $81 \%$. The magnitude of decrease was higher than what was observed during a tidal cycle (Table 1) so it truly represented changes

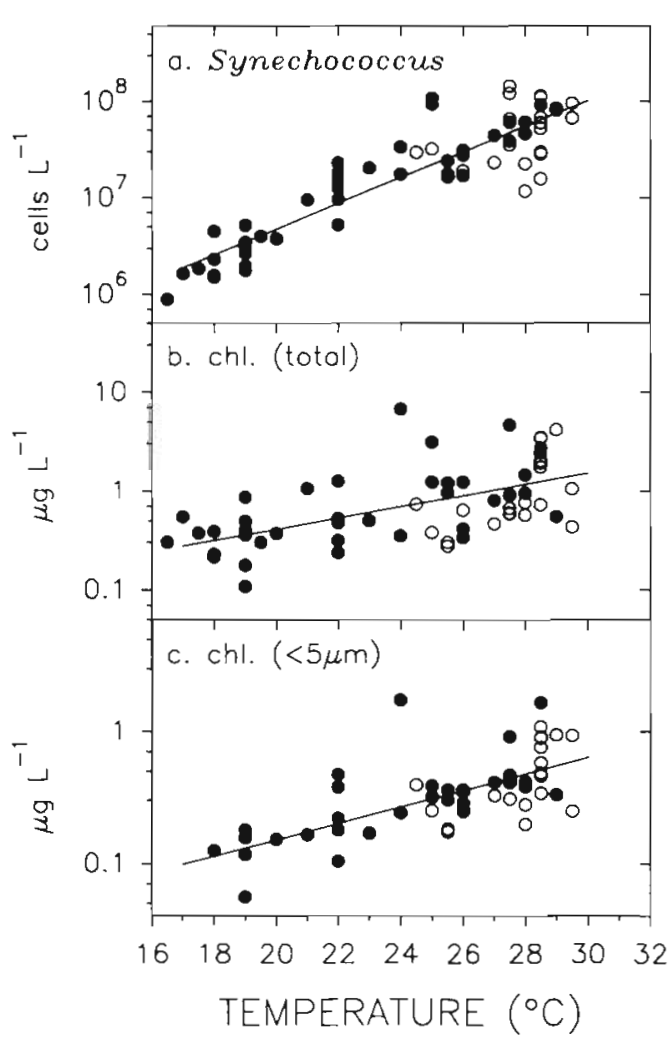

Fig. 5. Relationship between water temperature $(T)$ and (a) Synechococcus abundance (Syn); (b) total chl a concentration

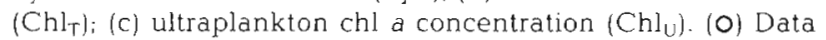
collected in the cyclone season (July and August). Regression equations are:

$\log (\operatorname{Syn})=4.016+0.133 T(\mathrm{r}=0.902, \mathrm{p}<0.001)$

$\log \left(\mathrm{Chl}_{\mathrm{T}}\right)=-1.526+0.057 \mathrm{~T}(\mathrm{r}=0.590, \mathrm{p}<0.001)$

$\log \left(\mathrm{Chl}_{U}\right)=-2.059+0.062 T(\mathrm{r}=0.673, \mathrm{p}<0.001)$

caused by cyclones. It has been reported that sea water in lagoons was replaced by oceanic water, and such a process lowered chl a concentration during a cyclone event (Delesalle et al. 1993). However, neither mixing with offshore water nor the dilution effects of heavy rainfall could satisfactorily explain the cycloneinduced chlorophyll decrease at our coastal station. In our study area, the difference in phytoplankton abundance between the inshore and offshore waters was not large enough to create the observed decrease (Fig. 3). As for the effects of rain water, typhoon Doug brought precipitation as high as $178 \mathrm{~mm}$ in $1 \mathrm{~d}$, but the change in salinity was only 0.7 (data not shown). Similarly, a wind event in the Sargasso Sea decreased chl a level in the entire water column instead of just flattening the vertical distribution (Mara et al. 1990). In Jamaica, a heavy rain significantly reduced salinity in coastal waters yet phytoplankton biomass was not affected (Webber et al. 1992). 
Alternatively, the decrease in chl a concentration must have been caused by other cyclone-related factors. Phytoplankton cells are known to be damaged by strong shear (Thomas \& Gibson 1990). Another effect of elevated mixing strength is to promote the coagulation of algal cells (Kiorboe et al. 1990). In addition, zooplankton grazing becomes more active in a turbulent environment (Kiorboe 1993, Hwang et al. 1994). More work is required to clarify how these factors may negatively affect phytoplankton abundance at our study site.

The sudden increase in dissolved nutrients after cyclones and heavy rainfalls is well documented (Webber et al. 1992, Delesalle et al. 1993). The sources of these nutrients may come from either the resuspended sediments or terrestrial runoff (Furnas 1989). The newly introduced nutrients apparently stimulated phytoplankton blooms at our coastal station (Fig. 4), and thus view was supported by subsequent observations in the following year. During the summer of 1995 the northern coast of Taiwan was not visited by any typhoon. The nitrate concentrations from June to early September were constantly lower than $5 \mu \mathrm{M}$, the summer phytoplankton blooms occurred less frequently, and the peak chlorophyll concentrations were lower than the 1994 level ( $\mathrm{J}$. Chang unpubl. result). However, the nutrient uptake processes and the population growth of phytoplankton did not occur simultaneously (Mara et al. 1990). Most of the nutrients were consumed in several days after a passing typhoon while the corresponding phytoplankton bloom appeared at a much later time (Fig 4).

Following a cyclone event, the pattern of recovery was different for large and small phytoplankton. The response of small species was fast. Immediately after the stormy period, both Synechococcus abundance and ultraplankton chl a started to climb. Usually, the increase in biomass lasted for 3 to $4 \mathrm{~d}$, and then reached a plateau (Fig. 4c). Since Synechococcus is believed to be able to grow at maximum rate using regenerated nutrients alone, the additional nutrients introduced by cyclones should have little influence on its growth rate (Hopcroft \& Roff 1990). Furthermore, small phytoplankton is mainly consumed by unicellular organisms that can multiply rapidly even under storm conditions (Nielsen \& Kiørboe 1991). Therefore, once the coupling between growth and grazing was restored to the pre-cyclone condition for Synechococcus, the accumulation of biomass would stop (Kiørboe 1993)

In contrast, phytoplankton larger than $5 \mu \mathrm{m}$ appeared to be in a lag phase when ultraplankton grew actively. After ultraplankton biomass leveled off, larger species started to grow for 10 to $20 \mathrm{~d}$ and eventually formed a bloom in the water column (Fig. $4 \mathrm{c}$ ). A plausible explanation is that the elevated nutrient level after a wind event reduces the competition for nutrients between large and small phytoplankton species so that the photosynthetic rate of the former group is enhanced (Delesalle et al. 1993, Kiørboe 1993). In addition, since large phytoplankton is mainly grazed by metazoan grazers with long generation time, the grazing pressure will not be able to keep up with the phytoplankton growth (Kiørboe 1993). Both of the mechanisms favor the formation of blooms

Our results indicated that, while quantitative differences existed between individual events, cyclones disturbed the coastal ecosystem in an ordered and predictable sequence (Fig. 4). Furthermore, the factors that caused these sequential changes, such as increased mixing strength and nutrient enrichment, seemed to have no difference from controlling factors reported for other storm related disturbances (Mara et al. 1990, Nielsen \& Kiørboe 1991). If so, cyclonic disturbances should greatly enhance the new production and the sinking flux of organic carbon in this subtropical coastal ecosystem as well. The validity of this deduction apparently demands further investigations.

Acknowledgements. We thank K.-M. Chen. H.-T. Yang, Y.-P. Chang, W.-R. Yang, Y.-H. Wen, and C.-C. Leu for therr assistance in sampling and nutrient analysis. This work was supported by R.O.C. National Science Council grant NSC840115-C019-01-032M, NSC83-0209-H019-007K, and NSC842611-M019-002K2

\section{LITERATURE CITED}

Delesalle B, Pichon M, Frankignoulle M, Gattuso JP (1993) Effects of a cyclone on coral reef phytoplankton biomass, primary production and composition (Moorea Island, French Polynesia). J Plankton Res 15:1413-1423

Furnas MJ (1989) Cyclonic disturbance and a phytoplankton bloom in a tropical shelf ecosystem. In: Okaichi T, Anderson DM, Nemoto T (eds) Red tides: biology, environmental science, and toxicology. Elsevier Science Publishing Co, New York, p 273-276

Goldman JC (1988) Spatıal and temporal discontinuities of biological processes in pelagic surface waters. In: Rothschild BJ (ed) Toward a theory on biological-physical interartions in the world ocean. Kluwer Academic Publishers, Dordrecht, p 273-296

Hopcroft RR, Roff JC (1990) Phytoplankton size fractions in a tropical neritic ecosystem near Kingston, Jamaica J Plankton Res 12:1069-1088

Hwang JS, Costello JH, Strickler JR (1994) Copepod grazing in turbulent flow: elevated foraging behavior and habituation of escape responses. J Plankton Res 16:421-431

Kiørboe T (1993) Turbulence, phytoplankton cell size, and the structure of pelagic food webs. Adv Mar Biol 29:1-72

Kiorboe T, Andersen KP, Dam. HG (1990) Coagulation efficiency and aggregate formation in marine phytoplankton. Mar Biol 107:235-245

Malone TC, Pike SE, Conley DJ (1993) Transient variations in phytoplankton productivity at the JGOFS Bermuda time series station. Deep Sea Res 40:903-924 
Mara J, Bidigare RR, Dickey TD (1990) Nutrients and mixing, chlorophyll and phytoplankton growth. Deep Sea Res 37 : 127-143

Nielsen TG, Kiørboe T (1991) Effects of a storm event on the structure of the pelagic food web with special emphasis on planktonic ciliates. J Plankton Res 13:35-51

Pai SC, Yang CC, Riley JP (1990) Formation kinetics of the pink azo dye in the determination of nitrite in natural waters. Analyt Chim Acta 232.345-349

Parsons TR, Maita Y, Lalli CM (1984) A manual of chemical and biological methods for seawater analysis. Pergamon Press, Oxford

Peterson WT (1986) The etlects of seasonal variation in stratification on plankton dynamics in Long Island Sound. In: Bowman MJ, Yentsch CM, Peterson WT (eds) Tidal mixing and plankton dynamics. Springer-Verlag, Berlin, p 297-320

Platt T, Harrison WG (1985) Biogenic fluxes of carbon and

This article was submitted to the editor oxygen in the ocean. Nature 318:55-58

Taylor GT (1989) Variability in the vertical flux of microorganisms and biogenic materal in the epipelagic zone of a North Pacific central gyre station. Deep Sea Res 36: $1287-1308$

Thomas WH, Gibson CH (1990) Quantified small-scale turbulence inhibits a red tide dinoflagellate. Gonyaulax polyedra Stein. Deep Sea Res 37:1583-1593

Throndsen J (1978) Preservation and storage. In: Sournia A (ed) Phytoplankton manual. UNESCO. Paris, p 69-74

Waterbury JB, Watson SW, Valois FW, Franks DG (1987) Biological and ecological characterization of the marine unicellular cyanobacterium Synechococcus. In: Platt T, L1 WKW (eds) Photosynthetic picoplankton. Can Bull Fish Aquat Sci 214:71-120

Webber DF, Webber MK, Roff JC (1992) Effects of flood waters on the planktonic community of the Hellshire Coast, Southeast Jamaica. Biotropica 24:362-374

Manuscript first received: July 25, 1995

Revised version accepted: May 6, 1996 